\title{
MOTOBOYS, CIRCULAÇÃO E TRABALHO PRECÁRIO NA CIDADE DE SÃO PAULO
}

\author{
Ricardo Barbosa da Silva*
}

\section{RESUMO:}

A atividade profissional dos motoboys aparece como produto e necessidade de um contexto histórico de fin de siècle, revelando parte das transformações socioespaciais na cidade de São Paulo na transição do século XX para o XXI, e encarnando dois pólos de um mesmo problema a partir da nova condição da cidade e do mundo do trabalho.

PALAVRAS-CHAVE: Cidade; Espaço; Circulação, Trabalho Precário, Motoboys

\section{ABSTRACT:}

The professional activity of motoboys appears as product and necessity of a historical context of fin de siècle, revealing part of the socio-spatial transformations in the city of São Paulo in the transistion of century XX for the XXI, embodying two poles of the same problem from the new condition of the city and the world of the work.

KEYWORDS: City; Space; Circulation Precarious Work, Motoboys

\section{Introdução}

A atividade profissional dos motoboys é um fenômeno urbano bastante recente: tem suas origens em meados da década de 80 e impulso definitivo nos prelúdios da década de 90 (OLIVEIRA, 2003, p. 38) e, indubitavelmente, é cada vez mais integrado à paisagem urbana da cidade de São Paulo.

Porém, devido ao seu rápido e exponencial crescimento ${ }^{1}$, aliado à dinâmica e a natureza de sua atividade profissional, os motoboys passam a ser alvos certos e constantes nas mais diversas controvérsias nas ruas e avenidas de São Paulo, pondo ainda mais combustão no seu conflituoso no trânsito.

São justamente os motoboys no trânsito que, entre insultos e gentilezas, entre agressões físicas e morais, entre um acidente e outro, entre um retrovisor que cai e uma porta que amassa, aceleram forte, pois, antes de tudo, a entrega precisa chegar ao seu destino certo e no tempo previsto. São eles, os chamados cachorros loucos $^{2}$, que expõem vivas as estratégias e as lógicas do capitalismo contemporâneo como forma de garantir no espaço as exigências da circulação fluída, de modo a garantir acumulação sempre ampliada do sistema capitalista na cidade de São Paulo.

E é nesta relação tênue entre o motoboy e a cidade, entre as exigências do tempo e limites do espaço, entre a expectativa e a satisfação das entregas rápidas, entre o luxo e a precariedade, entre o imprescindível e o estigmatizado, entre a vida e o desalento da morte, que a atividade profissional dos motoboys liga-se a uma nova prática socioespacial na cidade de São Paulo.

E é sobre essa nova prática em uma nova condição da cidade e do mundo do trabalho que esta análise deter-se-á. É neste sentido que este artigo visa demonstrar que a problemática da atividade dos motoboys não começa e nem encerra em si mesma. Não pretende classificá- 
los enquanto heróis ou vilões do trânsito paulistano. Nem mesmo associar seu modus operandi no trânsito como resultado, estritamente, de sua imperícia e imprudência individual. Mas, antes de tudo, compreender essa atividade profissional como produto e necessidade de um contexto histórico de fin de siècle, que revelam parte das transformações socioespaciais na cidade paulistana na transição do século $X X$, já que contraditoriamente é submetida e reproduz as estratégias e as racionalidades do capitalismo contemporâneo como forma de garantir as exigências da circulação fluida no espaço, possibilitando realização de parte do consumo em escala ampliada na cidade de São Paulo.

Essa análise a partir da atividade profissional dos motoboys permite, então, analisar parte das transformações socioespaciais na cidade paulistana na transição do século XX para o XXI, encarnando dois pólos de um mesmo problema: uma nova condição da cidade e do mundo do trabalho, traduzindo assim, uma nova prática socioespacial, definindo certos usos, formas de apropriação, intensidade de circulação e as condições de acessibilidades ao espaço urbano.

\section{Na Garupa do Trabalho Precário: características e condições de trabalho dos motoboys}

O mundo contemporâneo, que desponta embalado por uma nova etapa do capitalismo na transição do século XX para o XXI, revelase permeado por transformações socioespaciais, reagindo, dialeticamente, na estrutura da sociedade, da economia e do espaço geográfico.

Mas essas transformações não se apresentam como ruptura do sistema capitalista (HARVEY, 1996, p.164). Nem mesmo aparecem dando cabo à centralidade da categoria trabalho na contemporaneidade (ANTUNES, 2003, p. 83). Ao contrário, no fundo, o estabelecimento desse processo revela-se como um estágio superior do desenvolvimento antagônico das forças produtivas do capitalismo moderno, que se traduz na transição - não substituição - de um modelo de acumulação fordista para um de acumulação flexível (HARVEY, 1996; ANTUNES, 2003; SOJA, 1993).

À primeira vista, as transformações no regime de acumulação parecem vincular-se estritamente aos escopos da economia, de fato, espraia-se na emergência de novas práticas sociais e políticas, de novos padrões de consumo e um crescente setor de serviços, ditando uma série de novas mudanças nas práticas econômicas, políticas, culturais e espaciais (HARVEY, 1996, p. 140; GOTTDIENER, 1990, p. 59; BENKO, 1996).

No fundo, esse novo modelo de acumulação, que se reveste do jargão flexível $^{3}$, evidencia o histórico processo antagônico do capitalismo que se impinge, dialeticamente, através da estratégia de precarização do trabalho de modo a diminuir os custos produtivos (CACCIAMALI, 2002; MARTINS, 1994, p. 109; ALVES, 2000, p. 24) que articulada a uma sociedade de mercado, embala a cidade inteira sob um ritmo cada vez mais acelerado do giro do capital, dando gás a uma nova prática socioespacial sob a batuta do consumismo.

E é sobre as transformações socioespaciais na cidade e no mundo do trabalho que a atividade profissional dos motoboys se traduz como um ângulo privilegiado de análise. Pois essa atividade - impulsionada pelas altas taxas de desemprego (Gráfico 1), pelo intenso crescimento do setor de serviços (Gráfico 2), pela implosão e junção de velhas e novas normas de regulamentações do trabalho, pelas novas práticas socioespaciais, voltadas para o consumo desenfreado em um espaço onde a exigência é a circulação sempre fluída, - conecta-se a uma densa rede informacional articulada a uma espécie de gestão da circulação no espaço urbano, que visa garantir a circulação fluída de mercadorias, pessoas e informações que de forma mais ou menos aguda vem revelando as condições e as contradições de uma das mais predatórias atividades profissionais da cidade de São Paulo, principalmente, para um verdadeiro batalhão de motoboys que se enquadram no precário mundo do trabalho. 


\section{Gráfico}

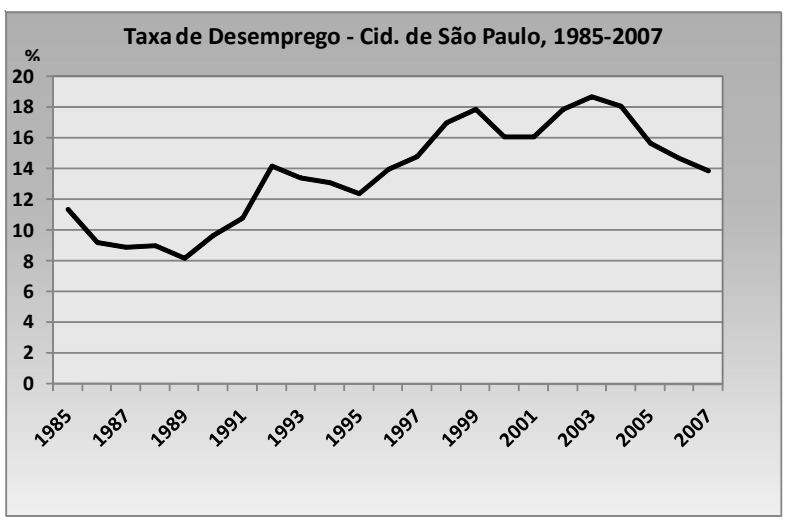

Fonte: Convênio SEADE-DIEESE.

Organizado por Ricardo Barbosa da Silva.

A categoria profissional, usualmente, chamada de motoboys recebe diversas denominações pela sociedade. E como se trata de trabalhadores que despertam sentimentos que variam do amor ao ódio muito rapidamente, alguns se limitam a tentar denominá-los simplesmente de motociclistas ou motoqueiros, outras tantos, não se prestam a mais do que estigmatizá-los, sendo chamados por um sem número de pessoas - inclusive por eles mesmos - de cachorros loucos.

No caso da Prefeitura do Município de São Paulo, a Lei No 14.491, de 27 de julho de 2007, no Art. $30, \mathrm{VII}$, retrata-os a partir do termo motofrete, que se refere à: "modalidade de transporte remunerado de pequenas cargas ou volumes em motocicleta, com equipamento adequado para acondicionamento de carga, nela instalado para esse fim". Em 2003, o Ministério do Trabalho e Emprego, define essa categoria a partir da Classificação Brasileira de Ocupações, no registro no 5191-10, "Motociclista no transporte de documentos e pequenos volumes - Motoboys" (MINISTÉRIO DO TRABALHO E EMPREGO, 2006).

Entretanto, nesta pesquisa, a denominação utilizada será a de motoboys, uma vez que, não é a nossa intenção buscar uma

\section{Gráfico}

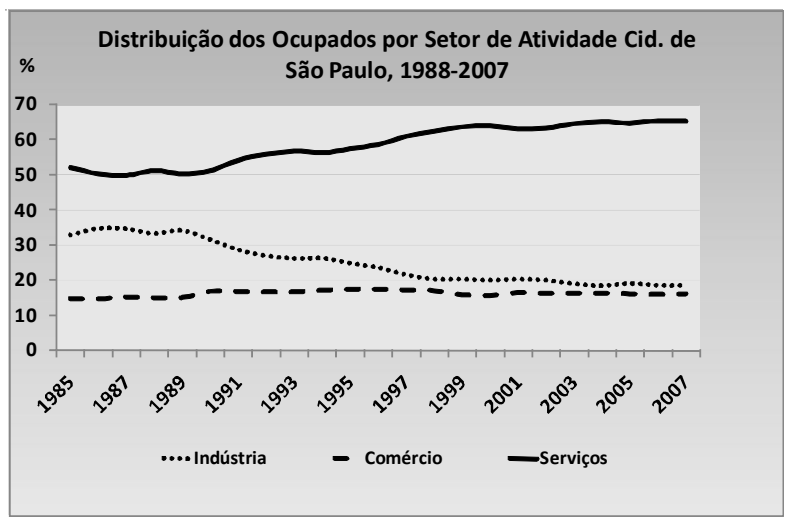

Fonte: SEADE-DIEESE.

Organizado por Ricardo Barbosa da Silva.

melhor definição etimológica para esta categoria profissional. A palavra motoboy, de origem inglesa, é um neologismo composto pela junção de duas palavras ( motorcycle $=$ moto e boy= garoto). E muito provável que as transformações no mundo do trabalho tenham contribuído para a proliferação do motoboy, que seria uma espécie de metamorfose circulante do antigo office-boy. Sabe-se que o termo motoboy em si, carrega algumas imprecauções no que se refere à caracterização dessa atividade. Apesar da maioria deles pertencerem ao sexo masculino, não dá conta de explicar o fato de muitas mulheres ocuparem postos nessa atividade, como também, exclui uma parcela considerável de adultos que desempenham esta função. Entrementes, diante da força que o termo motoboy carrega tanto positivamente quanto negativamente, servir-seá dele para melhor ilustrar a problemática dessa classe trabalhadora.

De modo geral, essa é uma atividade relativamente recente na dinâmica urbana de São Paulo. Conforme Gilvando Oliveira relata:

A ocupação surgiu no Brasil, no início da década de 80 , mais precisamente no ano de 1984 . O primeiro empresário de serviços de motoentrega que se tem notícia foi Arturo Filosof, um argentino que, em 1984, trouxe a idéia de 
Buenos Aires para São Paulo, onde fundou a Diskboy. Sua empresa levou alguns meses para receber a primeira encomenda, mas em 1985 já era amplamente conhecida na cidade, sendo noticiada em vários jornais e revistas nacionais (2003, p. 38).

Neste momento, a Diskboy era a proprietária da frota de motos, todavia não demorou muito para ela tornar-se destaque na relação das empresas que mais cometeram infrações no trânsito: com 119 metros de multas [...] Essas infrações levaram a empresa a vender sua frota de 80 motos e contratar motociclista com moto própria, para se livrar das multas e por entender que o motoboy proprietário de seu veículo devia tornar-se mais responsável no trabalho (Ibid. p. 38).

Atualmente, a maioria, de um universo aproximado de 200 mil motoboys na cidade de São Paulo, é proprietária de suas motocicletas. Para eles possuir uma motocicleta tornou-se um ponto de partida para a inserção nesta atividade profissional, funcionando como um dos atributos de seleção nas empresas. Foi assim que contou o motoboy Marcos, de 27 anos, que nos disse: "tem que ter moto, se não, não trabalha. Geralmente a maioria tem sua moto própria. Se não tiver moto a empresa nem aceita. A empresa não quer ter vínculo nenhum". Questionei-o se a maioria dos motoboys era dona da sua própria motocicleta, ele confirmou: "a maioria tem, uns $90 \%$ ou mais". Além disso, a maior parte deles tem que arcar com as despesas de sua motocicleta. Sobre este assunto, o motoboy Carlos Eduardo, de 26 anos, confirma: "a maioria dos motoboys, uns $80 \%$, tem que bancar as despesas da moto". Entre essas despesas incluem-se equipamentos de segurança (capacete, colete, luvas, botas, mata-cachorro equipamento para proteção de membros inferiores -, antena - equipamento para proteção da integridade do condutor contra linhas de cerol de pipas, fios e cabos aéreos), as despesas com a manutenção e os reparos na motocicleta, além é claro, do combustível para abastecê-la.

A motocicleta como ponto de partida para o exercício da atividade dos motoboys foi possibilitado, em parte, pela maior facilidade de sua aquisição. Comprar uma motocicleta zero quilômetro de baixa cilindrada, como por exemplo o modelo Honda CG 150 Titan $^{4}$, custa aproximadamente $R \$ 6.200,00$, podendo ser financiada em até 48 parcelas em média de $R \$ 260,00$, sem contar, que o Banco do Brasil concedeu uma linha de crédito de $\mathrm{R} \$ 100$ milhões para financiamentos de motos de até $R \$ 8.500$, voltadas especificamente aos motoboys ${ }^{5}$ - este valor, superior ao preço da motocicleta, já leva em consideração os equipamentos necessários e obrigatórios para o desempenho da função de motoboy. Além disso, os motoboys têm a opção do consórcio com inúmeras parcelas e com juros mais convidativos, podendo parcelar a moto em 72 prestações de $\mathrm{R} \$ 110,00^{6}$.

De modo geral pode-se auferir que o crescimento da frota de motocicletas é um fenômeno nacional, impulsionado evidentemente pelas características socioespaciais particulares de cada lugar. As motocicletas têm um uso bastante variado no território brasileiro,e mais do que isso, elas vêm reforçando e alterando alguns hábitos. Usadas para lazer e veraneio nas mais recônditas localidades desse país, ela possibilita aos mais pobres algo até algum tempo atrás reservado aos mais abastados. No meio rural, a paisagem antes tomada por animais que serviam de transportes e às mais variadas funções, mudou. Hoje eles foram relegados à própria sorte sob o revés dos peões de duas rodas. Nas pequenas e médias cidades, como também, nas periferias socioespaciais de algumas grandes cidades, já funcionam o serviço de moto-táxi ${ }^{7}$, justamente em espaços sociais que ainda estocam a confiança e solidariedade entre os pares, sem contar que nas periferias as motocicletas conseguem vencer uma geografia toda particular, baseada numa emaranhada trama de ruas e vielas que se acotovelam num território esquecido pelo poder político. Nas grandes cidades, como diria Jane Jacobs ${ }^{8}$ (1961) o lugar "cheio de estranhos" (full of strangers), o perigo de assalto que o anonimato proporciona e a iminência de acidentes de trânsito é o gás para a motocicleta proliferar menos como moto-táxi do que como meio de transporte sob conta e risco do indivíduo que a 
pilota fugindo do ineficiente transporte público da metrópole e, também, como uma importante fonte de trabalho e renda para um contingente imenso de motoboys, incluídos nas hastes precárias do mundo do trabalho.

Não por acaso, no Brasil, em 2000, conforme dados do Departamento Nacional de Trânsito (Denatran), circulavam cerca de 3.550.177 de motocicletas, já em 2008, o número chegou a 11.045 .686 , representando um crescimento em torno de $305 \%$ no período citado. Sendo que em 2008 as motocicletas no Estado e cidade de São Paulo representavam, respectivamente, aproximadamente $23 \%$ e algo em torno de $6 \%$ do total da frota brasileira ${ }^{9}$.
Neste mesmo roldão a frota de motocicletas na cidade de São Paulo vem apresentando um intenso crescimento. Segundo o Departamento Estadual de Trânsito de São Paulo (Detran-SP), em 2000, a frota chegava a 348.098 motocicletas, passando para 658.973 motocicletas, em 2008, o que representa um acréscimo aproximado de $90 \%$ no período. Sem contar que a participação da motocicleta no trânsito subiu de $7 \%$, em 2000 , para $11 \%$, em 2008 , do total dos veículos na cidade de São Paulo, o que representa cerca de $58 \%$ de aumento ${ }^{10}$ (Gráfico 3).

Mesmo sem uma evidência mais rigorosa do ponto de vista empírico que comprove o

\section{Gráfico}

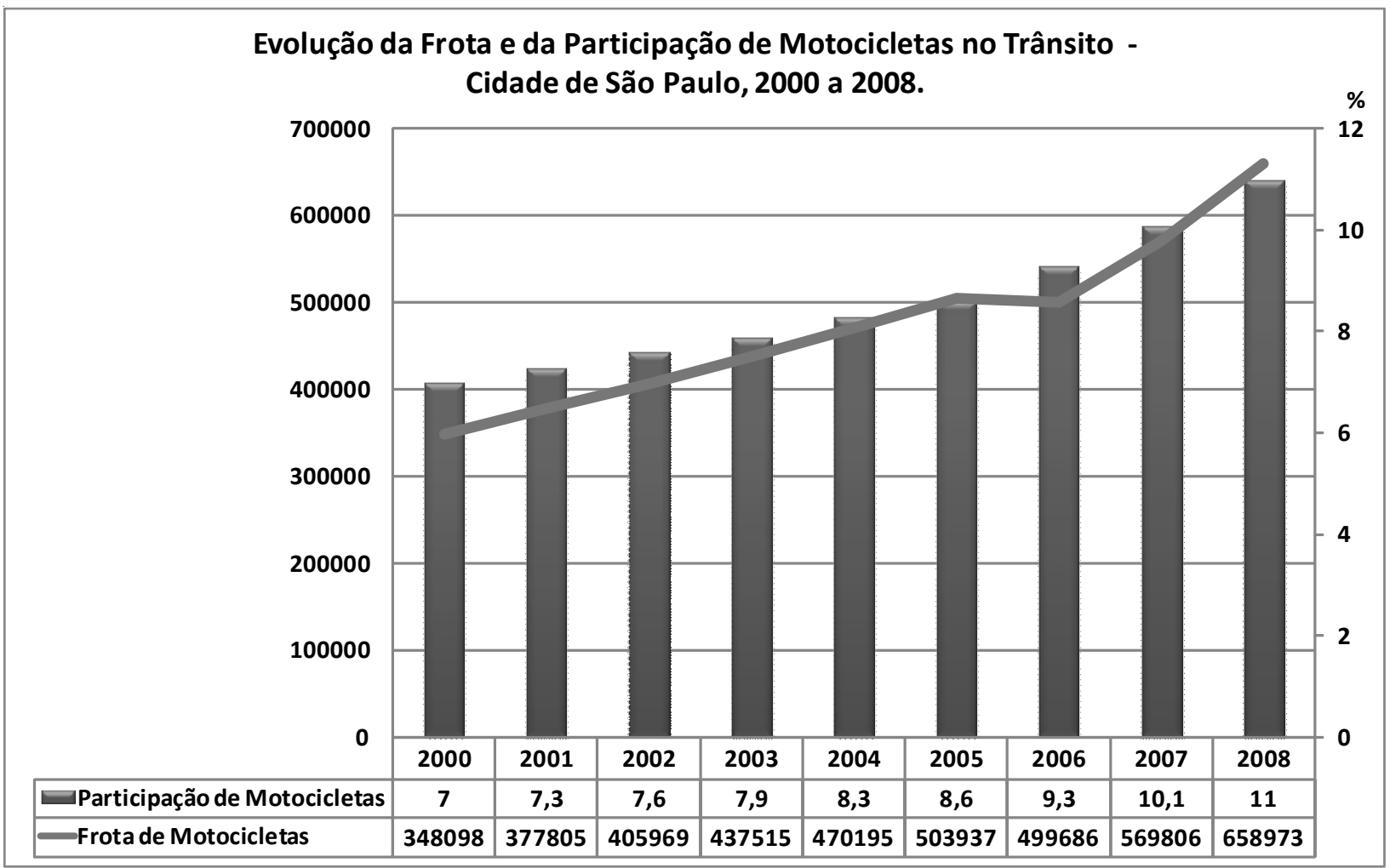

Fonte: DETRAN-SP

Organizado por Ricardo Barbosa da Silva. 
crescimento e o tamanho mais próximo possível da realidade acerca da atividade profissional dos motoboys, é inegavelmente um fenômeno urbano visto à olhos nus nas ruas e avenidas das grandes cidades do Brasil. Em entrevista a nós concedida, Gilberto Almeida dos Santos, o "Gil", Presidente do Sindicato dos Mensageiros Motociclistas, Ciclistas e Moto-Taxistas do Estado de São Paulo, disse-nos assim sobre a questão: "creio que entre 200 e 250 mil só na cidade de São Paulo". Deste montante, indubitavelmente, a atividade dos motoboys representa uma parcela considerável desse mercado. Segundo Aldemir Martins de Freitas, o "Alemão", Presidente do Sindicato dos Trabalhadores Motociclistas da Cidade de São

\section{Gráfico}

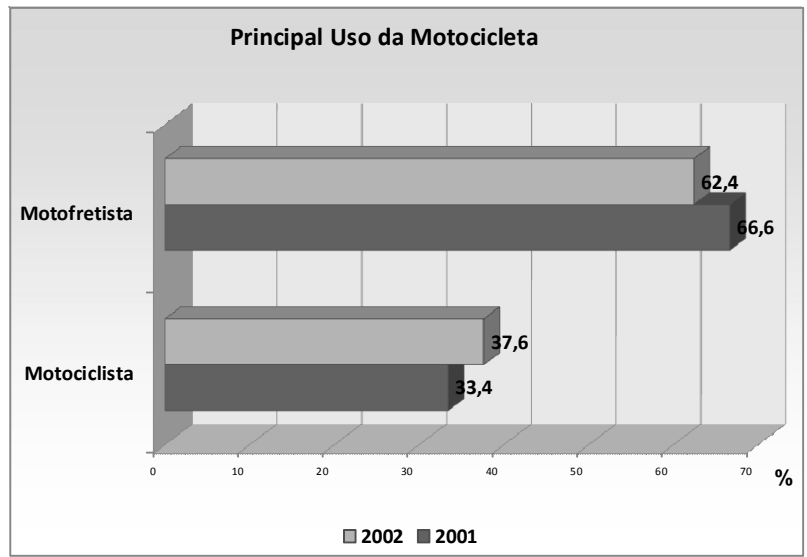

Fonte: CET, 2002-2003

Organizado por Ricardo Barbosa da Silva.

Neste esteio, quando a questão refere-se ao gênero é patente o predomínio do sexo masculino, os números que giram em torno de $99 \%$ do total (Gráfico 6). No que se refere à escolaridade, pode ser verificado que $40 \%$ dos motoboys possuem o Ensino Fundamental II, 26\% o Ensino Médio e 10\% têm Ensino Superior. Porcentagens relativamente abaixo quando comparadas às dos motociclistas, nas quais $24 \%$ deles possuem o Ensino Fundamental II, 47\% o Ensino Médio e $28 \%$ o Ensino Superior (Gráfico 7).

Um dos quesitos que salta aos olhos concerne à faixa etária dos motoboys, observa-
Paulo, há uma estimativa que a cada dez motocicletas Honda CG de baixa cilindrada vendidas, sete são para os motoboys.

Deste universo de motocicletas, indubitavelmente, a atividade dos motoboys compõe-se de uma parcela considerável. Em um estudo publicado pela Companhia de Engenharia de Tráfego - CET ${ }^{11}$, em 2002, foram entrevistados 999 motociclistas na cidade de São Paulo, desses cerca de $66 \%$ eram motoboys e $34 \%$ deles eram motociclistas (usavam a moto como meio de transporte ou lazer). Em outro estudo publicado pela CET $^{12}$, em 2003, dos 1141 motociclistas entrevistados, $62 \%$ eram motoboys e $38 \%$ eram motociclistas $^{13}$ (Gráfico 5).

\section{Gráfico}

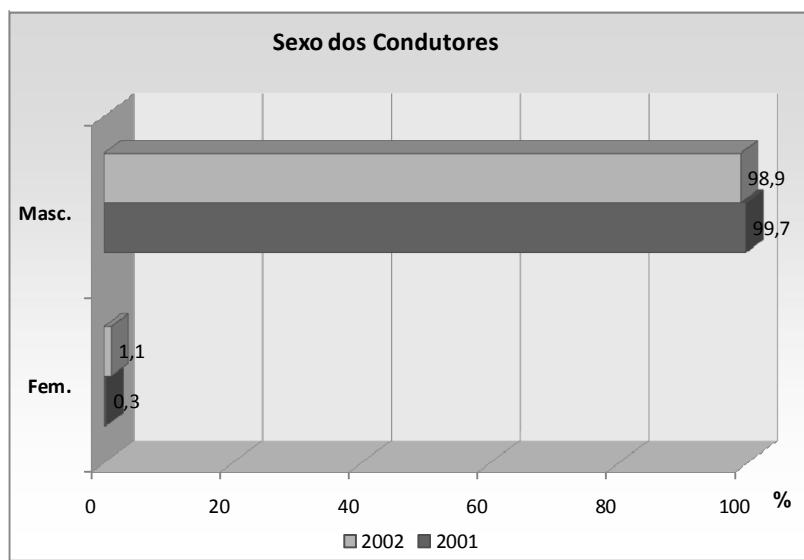

Fonte: CET, 2002-2003

Organizado por Ricardo Barbosa da Silva

se um predomínio de jovens entre 20 e 24 anos, que representam $32 \%$ do total. E ainda, se agruparmos aqueles da faixa etária de 18 a 29 percebe-se um predomínio de $77 \%$. Já no que tange aos motociclistas há um predomínio de $22 \%$ entre 25 e 29 anos. Contudo, somando-os de 18 a 29 anos chega-se a $51 \%$ do total. Em síntese, pode-se auferir em relação ao uso de motocicletas, que é um fenômeno com maior presença entre os jovens, entrementes, se a análise se limita aos motoboys, percebe-se o fenômeno marcante que de 10 motoboys, aproximadamente 8 são jovens ${ }^{14}$ (Gráfico 8 ). 


\section{Gráfico}

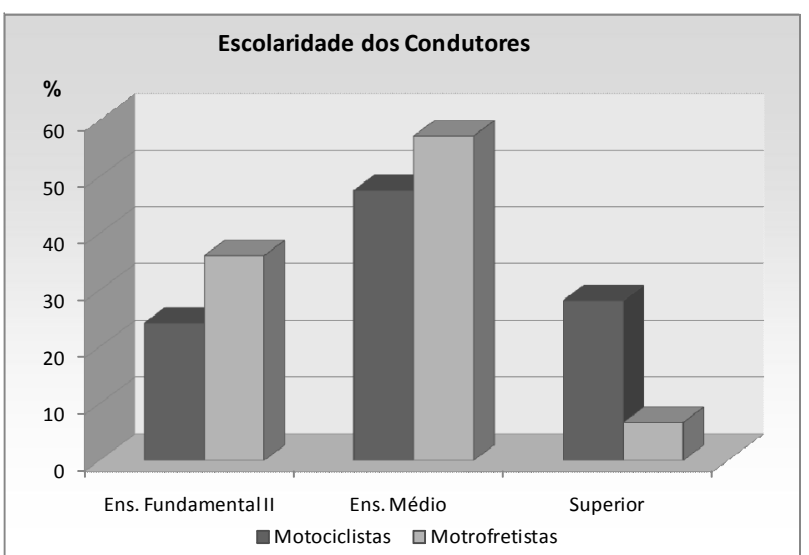

Fonte: CET, 2003

Organizado por Ricardo Barbosa da Silva

Para Heloísa Martins, da Cia. de Engenharia de Tráfego (CET), a atividade dos motoboys aparece como uma oportunidade para os jovens com baixa qualificação que não conseguiram se inserir no mercado de trabalho:

eu acho que o trabalho do motofrete surgiu em São Paulo como uma oportunidade, para uma grande quantidade de jovens desempregado sem qualificação, que devido o desenvolvimento das forças produtivas atualmente a falta de qualificação vai manter essa gente sem emprego. Cada vez é necessário ter um diferencial para se colocar no mercado de trabalho, então, pessoal que só fez o ensino médio, não fala bem o português, não apresenta nada de diferente, fica entre a opção de trabalhar como ajudante, auxiliar ou coisas assim e ganha até 500 reais por mês. O motofretista tem hoje um piso de 650 reais, ele aluga a motocicleta e ganha produtividade, se ele fizer mais entregas, tem lá motofretistas que chegam a ganhar 2000 reais, essa é uma excelente profissão pra quem não tem opção.

Mas a necessidade de salientar o expressivo percentual de jovens na garupa de
8. Gráfico

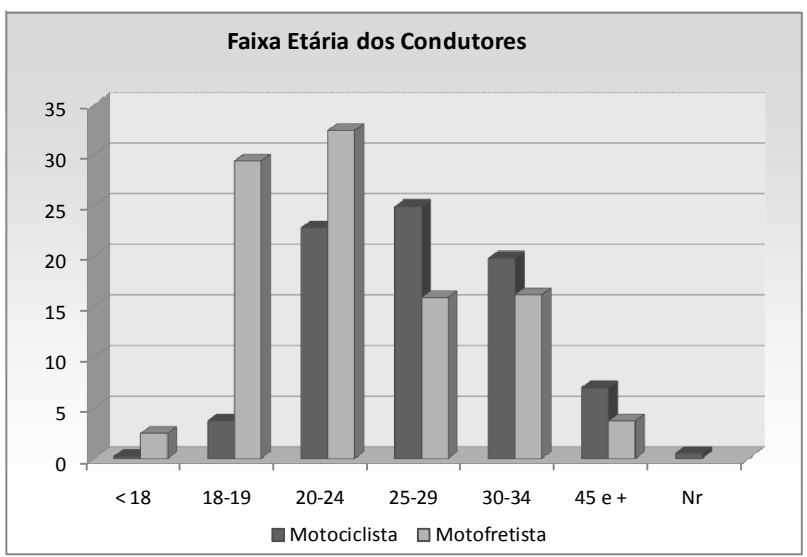

Fonte: CET, 2003

Organizado por Ricardo Barbosa da Silva

motocicletas faz necessário frisar que esta atividade comporta pelo menos duas gerações. Obviamente, sem buscar uma generalização definidora, pode-se notar a primeira geração, que é resultado direto do processo de reestruturação produtiva na metrópole de São Paulo, que levou milhares de trabalhadores na condição de desempregados, muitas vezes, sem opção a se alocar nesta atividade profissional - que, à princípio, para muitos deles não representava mais do que um trabalho provisório. Mas devido às escassas oportunidades no mercado de trabalho, boa parte deles permaneceu nesta atividade - o que sem dúvida Ihes confere o título de pioneiros. Em entrevista a Natércio, 41 anos, apesar de trabalhar desde 1993, disse-me tinha gente com mais tempo do que ele nesta atividade, porém explicou-me como foi o início da atividade: "no começo não era a metade do que era antes. Hoje o pessoal se vê desempregado, a opção é comprar uma moto e trabalhar de motoqueiro". Perguntei-o se fora assim com ele, então respondeu: "quando eu comecei, eu estava desempregado. Mas eu já tinha uma moto. Ai passou um rapaz e perguntou se eu queria trabalhar, tava desempregado, me chamou, ai eu fui; na situação que eu tava, pagando aluguel". 
No trabalho de campo observa-se que a todo instante a primeira geração de motoboys tentava diferenciar-se da segunda geração não tanto pela idade, mas pelo maior traquejo e vivência no violento trânsito urbano. Para DINIZ (2003, p.16), os motoboys mais experientes: "encontram no saber acumulado e na rede solidária tecida com seus pares um meio para atenuar a densidade do trabalho e evitar os acidentes".

Já a segunda geração, aparece basicamente relacionada aos jovens que na sua maioria não conseguiram (e não vêm conseguindo) inserção em outra atividade formal no mercado de trabalho e, sem muitas opções, foram se aventurar como motoboy no trânsito urbano da metrópole. São eles, muitas vezes, os cachorros loucos que pilotam de forma perigosa e imprudente, expondo-se eminentemente aos riscos do trânsito urbano de São Paulo. É justamente, neste sentido, que o motoboy Irlei, 38 anos, relata-nos sobre a questão: "o cara mais novo corre por que não tem experiência. A empresa chega no cara e diz 'é pra ontem'. As vezes nem é tão urgente. Eu mesmo já peguei serviço aqui e ele falou 'vai lá que é da diretoria e é urgente', peguei, fui lá cadê o cara, tava viajando, era até um final de semana prolongado". Ainda sobre o tema, Natércio fala: "a diferença dessa garotada hoje, entre 18 a 25 anos, pra eles é aventura. É pegar o serviço e sair que nem doido na rua. Para eles é só temporário até achar um outro e sair. Em seguida, perguntei se mesmo com toda sua experiência ele também não cometia algum abuso, aí me disse: "não eu ando devagar, quem mais corre são os mais jovens de 18 a 25 anos, são estes quem geralmente estão caídos no chão, ainda mais a maioria são esporádicos". Porém, para Carlos, 22 anos, justifica: "pessoal mesmo que pega o ônibus, pessoal vê a gente passando rápido, o pessoal acha que o motoqueiro tá fazendo aquilo por que é motoqueiro é tudo cachorro loco, mas não, a gente tem que acelerar não tem jeito".

No fundo, a partir dessa maior exposição e pressão a que são submetidos no espaço e no tempo, os jovens motoboys traduzem-se como agentes de uma nova cartografia urbana, já que carregam o ímpeto e a rebeldia peculiar da idade que Ihes são características, somadas às racionalidades e lógicas das exigências da circulação rápida que Ihes são impostas a que os impõem. Assim, muito jovens motoboys montam em suas motocicletas tentando driblar as estatísticas da violência urbana nas periferias pobres para virar estatística no violento trânsito no coração da metrópole de São Paulo.

Embora os jovens motoboys mereçam atenção especial devido às condições de trabalho e aos riscos iminentes a que são submetidos, o que prevalece, em ambas gerações e independente do gênero, é a lógica do acelerador, da pressa desmedida, possibilitada por um processo de produção capitalista que visa à reprodução do espaço como espaço fluído, das vias expressas destinadas à dinamização da circulação, distribuição e das trocas de mercadorias. É assim que os motoboys são impulsionados a acelerar, a costurar em zigue-zague seu percurso, de maneira rápida e eficiente.

E é sob essa lógica que se garante parte da circulação rápida de uma infinidade de mercadorias de lojas diversas, de shoppings centers, do setor varejista, de séries infindáveis de mercadorias vendidas pelo telefone ou pela internet; ou mesmo, possibilitam a realização de entregas e de coletas de toda ordem vinculadas ao setor financeiro. Assim também, realiza-se entregas e coletas para cartórios, de exames médico-laboratoriais; sem contar, as redes de alimentação e fast-food, lanchonetes e pizzarias das mais sofisticadas às mais simples; as floriculturas, joalherias e, até mesmo, objetos diversos que remetem a valores sentimentais.

A atividade dos motoboys torna-se instrumento de mediação entre a voracidade de produção e consumo, deslocado do fator de produção dos desejos e necessidades frívolas que comandam o ato de consumir numa cidade contemporânea. É essa racionalidade que impõe a milhares de motoboys a necessidade de acelerar a mais de cem quilômetros por hora, de rodarem 
mais de 200 quilômetros por dia, muitas vezes, em dupla (ou tripla) jornada - chegando a cumprir até 16 horas de trabalho - mesmo, que no limite, vidas sejam ceifadas em nome dessa lógica hiperexploratória.

É neste sentido que a metrópole de São Paulo na transição do século XX para XXI, locus das estratégias globais da nova etapa do capitalismo articulado a um papel preponderante do mundo precário do trabalho, constitui-se, simultaneamente, como centro dinâmico da valorização do capital e locus da pobreza e dos problemas sociais, em especial, das condições sempre cambiantes e instáveis dos empregos, de desempregos, trabalhos precários, informais e outras tantas formas de inserção no mundo do trabalho.

É justamente nesta nova fase famigerada do sistema capitalista, na qual o desemprego mais do que cíclico, revela-se, antes de tudo, como estrutural (HOBSBAWN, 2003 p. 403; ANTUNES, 1995, p. 49; ALVES, 2000, p. 259), ou, entendido de outro modo, empregos perdidos não seriam mais repostos nem com os ciclos de crescimento econômico (GRANOU, 1975, p. 14; HOBSBAWN, 2003, p. 403). Mais do que isso, o caso brasileiro remete a contradições mais sobressalentes, em que a expansão do desemprego estrutural acabou produzindo uma estrutura social sui generis ena qual o precário de exceção vira a regra (CASTEL, 2005; OLIVEIRA, 2003).

\section{da Fluidez \\ Circulação no Espaço como Exigência}

Essas novas práticas socioespaciais ditadas pela transição de regimes de acumulação, no fundo, passariam a deixar cada vez mais suas marcas expressas no espaço urbano. O arquétipo dessa nova condição urbana traduzia-se pelo estabelecimento das cidades mundiais, vinculadas ao setor financeiro e de serviços (LENCIONE, 1998, p. 31; LEMOS; 2004, p. 119; SASSEN, 1993, p. 188; CASTELLS 1999, p. 476; CARLOS, 2001, p. 21).

É dessa forma que São Paulo, de locus e entreposto da indústria, passa a assumir cada vez mais a preponderância do setor de serviços. Milton Santos, analisando a realidade objetiva brasileira das grandes metrópoles como São Paulo, sublinha seus antagonismos por ele denominados de "modernidade incompleta":

Nela se justapõem e superpõe trocas de opulência, devido à pujança da vida econômica e suas expressões materiais e sinais de desfalecimento, graças ao atraso das estruturas sociais e políticas. Tudo que há de mais moderno pode aí ser encontrado, ao lado das ocorrências mais gritantes (SANTOS, 1990, p. 13).

É nesta medida que, São Paulo, no eixo das cidades mundiais, revela a mais grassa contradição da engenharia neoliberal, baseada na multiplicação do consumo em escala global, concomitante, à proeminência dos problemas sociais de toda ordem. É nesse espaço urbano produzido de modo a garantir a realização do ciclo do capital no espaço, já que "sem a circulação de bens não há circulação do excedente" (SANTOS, 2003, p. 144), que os motoboys são lançados como importantes instrumentos de realização dessa racionalidade. Isso porque os imperativos atuais da circulação no espaço, que se apoiam em novas formas, funções e processos e se inscrevem no espaço, baseados na lógica na qual a circulação passa a ser a exigência (Ibid., p. 275; Idem, 2003, p. 144) e o consumo a ordem (LEFEBVRE, 1969, p. 25; Idem, 1991, p.77), lançam os motoboys, sempre no limite do ponteiro do relógio, como mediadores dessa voracidade consumista de mercadorias e imediatista entrega de toda sorte.

É por este viés que a atividade dos motoboys na transição do século XX para o XXI torna-se um ângulo privilegiado de análise de modo a revelar as instâncias e as lógicas de poder econômico e político na cidade. Estas lógicas revelam-se de maneira mais evidente a partir das instâncias de poder do Estado que aparecem como um dos elos fundamentais, quer no sentido da realização do processo de reprodução do espaço, suas infraestruturas, como também, organizando e controlando o fluxo diário de pessoas e veículos; gerindo a 
velocidade, punindo os excessos e os conflitos, vigiando qualquer alteração que possa fugir de seu domínio e controle.

Porém uma cidade que se embala pelas racionalidades do consumo exacerbado, privilegiando historicamente um modelo de circulação baseado no automóvel (SANTOS, 2005, p.106; SCARLATO, 1981, p. 94; SCHOR, 1999, p. 41; OLIVA, 2004) quando pára ${ }^{15}$ - mesmo que provisoriamente - irrita os motoristas, os passageiros, os transeuntes; inviabiliza o comércio, a distribuição, a troca, a realização do capital. $E$, é neste interregno, que a figura do motoboys torna-se imprescindível. Uma atividade através da qual, por suas características, a lógica da circulação, a princípio, não é suspensa. Pois, em primeiro lugar, mesmo a cidade contando com um verdadeiro aparato a fim de garantir a realização da circulação e do consumo, está submetida aos mais variados problemas pontuais (condições climáticas adversas, acidentes de trânsito, manifestações públicas, etc.) e estruturais (construção e melhoramentos de avenidas e ruas, pontes, viadutos e túneis, melhoramento dos transportes públicos, etc). Em segundo lugar, independente das condições de tráfego, lento ou rápido, das condições climáticas, com chuva ou sol, os motoboys passam em disparada, soberanos, acelerando, buzinando, explodindo motores, serpenteando entre um carro e outro nas ruas e avenidas da grande cidade paulistana.

Todavia, os motoboys não são infalíveis. O tombo, o choque, faz a eficácia e a pressa transformarem-se em choro, em desalento. Todos param. Irresolutos, os motoboys observam mais um no asfalto. Entrementes, a lógica que parecia suspensa no seu limite último ganha um novo fôlego com mais um motoboy acionado pela empresa para retirar e entregar o envelope ou a mercadoria qualquer, daquele que ainda sobre o asfalto agoniza à espera de resgate, já que, antes de tudo, a entrega precisa chegar ao seu destino previamente combinado. A este respeito, o motoboy Donizete, 32 anos, conta-nos: "Se de repente você cai, você vai ficar largado na cama e ninguém quer saber, ninguém vai te dar auxilio nenhum, coloca outro no lugar. Às vezes pega o seu documento do chão [...] vem outro motoboy da mesma empresa e pega o documento do chão e sai véio". Questionado se já havia acontecido com ele, disse-me: "já me mandaram fazer isso. Um amigo nosso caiu aqui no elevado (Costa e Silva) e me ligaram pra ver onde eu estava; eu estava perto da praça da República e pediram que eu fosse lá pegar o trabalho pra terminar, só que eu cheguei lá e esperei o resgate chegar, ele ia ser atendido e depois eu fui fazer. Eu mesmo não acabei fazendo da forma que eles pediram. Pela empresa eu ia lá, pegava os documentos e deixava ele lá".

Destarte, para além do estabelecimento dessa nova prática socioespacial, onde o fugaz, o efêmero, o ritmo alucinante e frenético do dia-adia impresso no espaço que, em grande medida, vai caracterizando e ditando o surgimento dos motoboys como produto e necessidade da cidade de São Paulo na transição do século XX para o XXI, esta atividade revela-se, ainda, como uma das profissões de maiores riscos de acidentes com vítimas e acidentes fatais na cidade de São Paulo.

Não por acaso, aliando as condições objetivas da cidade e do mundo do trabalho, equacionadas a certas facilidades de se obter uma motocicleta, além do intenso incremento da frota de motocicleta, essa atividade acabou trazendo consigo um aumento substancial de acidentes de trânsito envolvendo moto. Para se ter uma ideia da dimensão desse problema, em 2006 ocorreram 11.286 ( $32 \%$ do total) acidentes com vítimas, cerca de 30 acidentes por dia, já em 2007 esse número passou para $15.193(55 \%$ do total), aproximadamente 41 acidentes com vítimas por dia (gráfico 9).

Do ponto de vista espacial, dos 11.286 ( $32 \%$ do total) acidentes com vítimas na cidade de São Paulo, em 2006, apesar de bem distribuídos, pode-se verificar em algumas avenidas uma maior concentração. Se juntarmos as duas marginais, o número de acidentes com vítimas chegou a 789, na Radial Leste esse número chegou a 379, na Av. 23 de maio ocorreram 369 acidentes, na Av. Aricanduva 251 acidentes com vítimas (mapa 1 ). Em relação 
aos acidentes fatais, em 2006, foram registrados 380 óbitos, algo próximo de 1 morte de motociclista por dia, desses - selecionados em 76 corredores - destacam-se as marginais com 37 óbitos (20 na Marginal Pinheiros e 17 na Marginal Tietê), as avenidas Aricanduva e Sen. Teotônio Vilela com 12 mortes em cada uma delas, a Estr. $M^{\prime}$ Boi Mirim com 11 acidentes fatais, a Av. Interlagos com 8, a Av. Robert Kennedy com 7 acidentes fatais, a Av. dos Bandeirantes com 6 e as avenidas Carlos Caldeira Filho, do Estado, Jacu-Pêssego, Radial Leste, Sadume Ivone e Sapopemba com 5 óbitos (mapa 2).

\section{Gráfico}

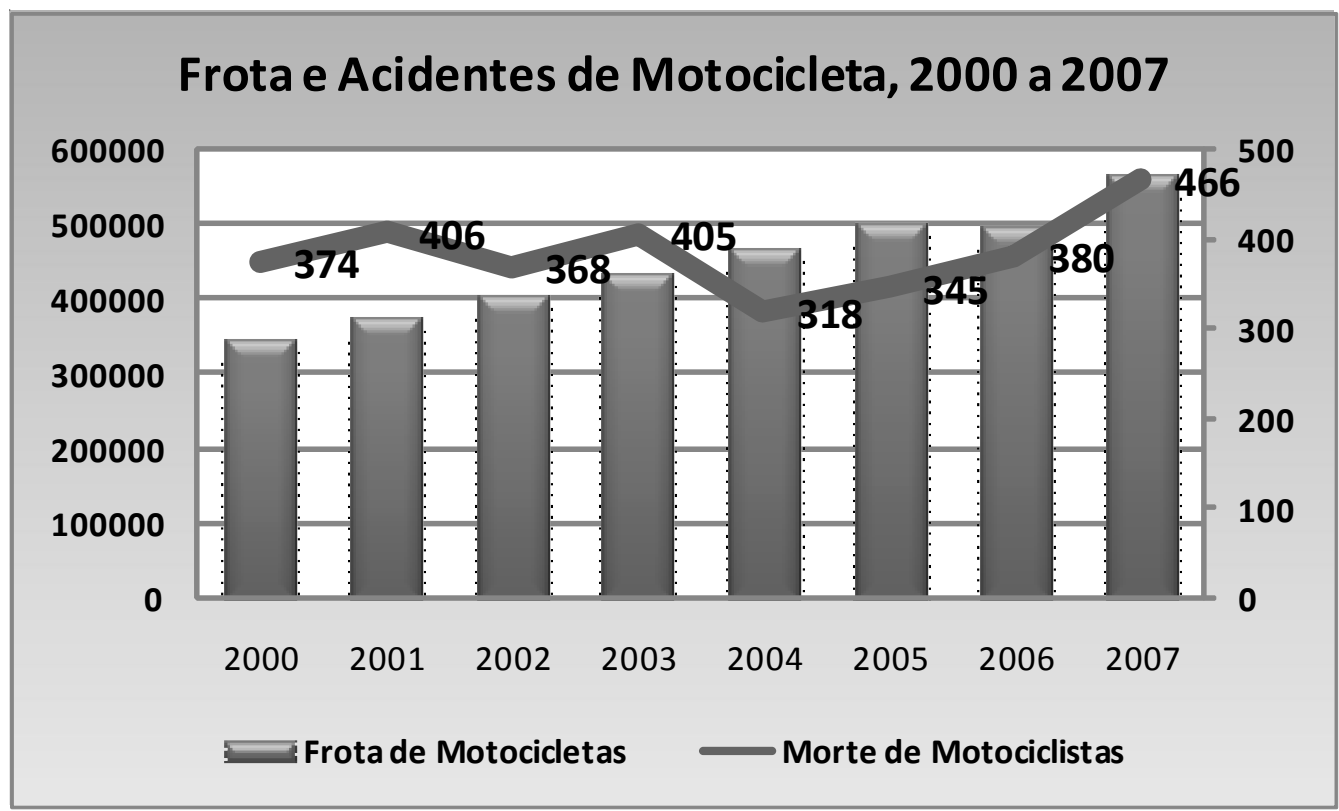

Fonte: CET/DETRAN

Organizado por Ricardo Barbosa da Silva

E esses acidentes envolvendo motocicletas em São Paulo, mais do que os altos custos - que atingem a ordem de $R \$ 373$ milhões de reais por ano ${ }^{16}$ - traduzem imediatamente um custo incomensurável, relacionado à perda da vida humana para a família de um ente querido, sendo os motoboys uma de suas principais vítimas, já que devido à natureza de sua atividade profissional, arriscam-se constantemente no perigoso trânsito da metrópole paulistana. Por isso é preciso repensar o espaço enquanto uso consciente e social para fazer frente à dita racionalidade e eficiência do sistema capitalista que vem ceifando às tontas a vida de nossos jovens e adultos, cheios de sonhos e esperança de um horizonte melhor.

É assim que esta abordagem insere-se na tentativa de superar uma discussão mais superficial - e, muitas vezes, preconceituosa e estigmatizante -, sobre o surgimento e a dinâmica dessa nova atividade profissional na cidade de São Paulo, com a intenção de contribuir à compreensão dessa atividade para além de um sentido de espontaneidade, como também, deslocar o foco constantemente ligado aos conflitos no trânsito do espaço urbano da cidade paulistana. O que denota uma maneira possível - não única - de revelar mais consistentemente 
a prática socioespacial da atividade profissional dos motoboys inserida nas lógicas e estratégias das relações sociais que reproduzem o espaço urbano e as suas próprias relações.

Mapa 1

Acidentes com Vítimas Envolvendo Motocicletas por Corredor Viário - Município de São Paulo, 2006

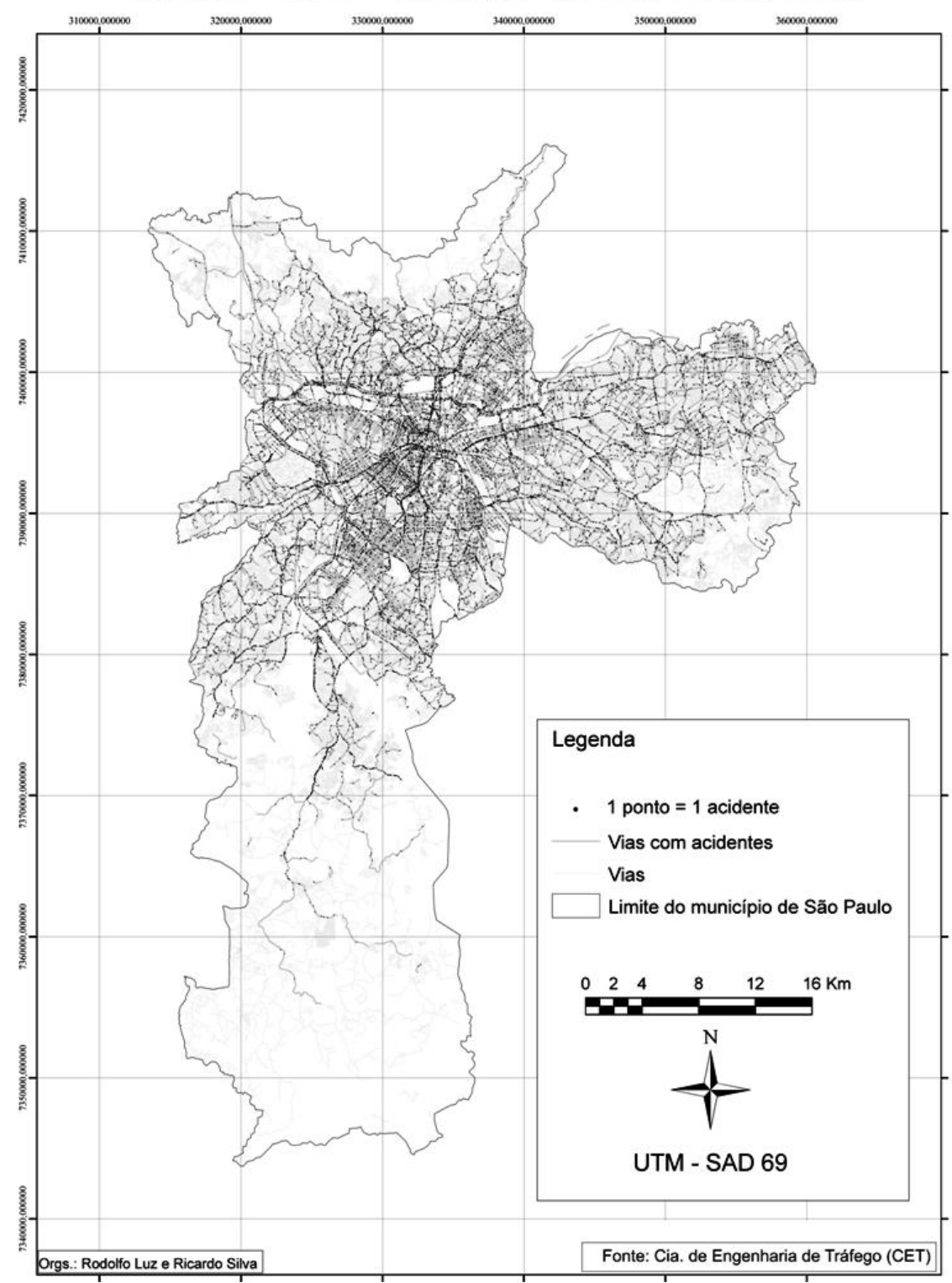


Mapa 2

Acidentes de Trânsito Fatais Envolvendo Motocicletas em Corredores Selecionados - Município de São Paulo, 2006

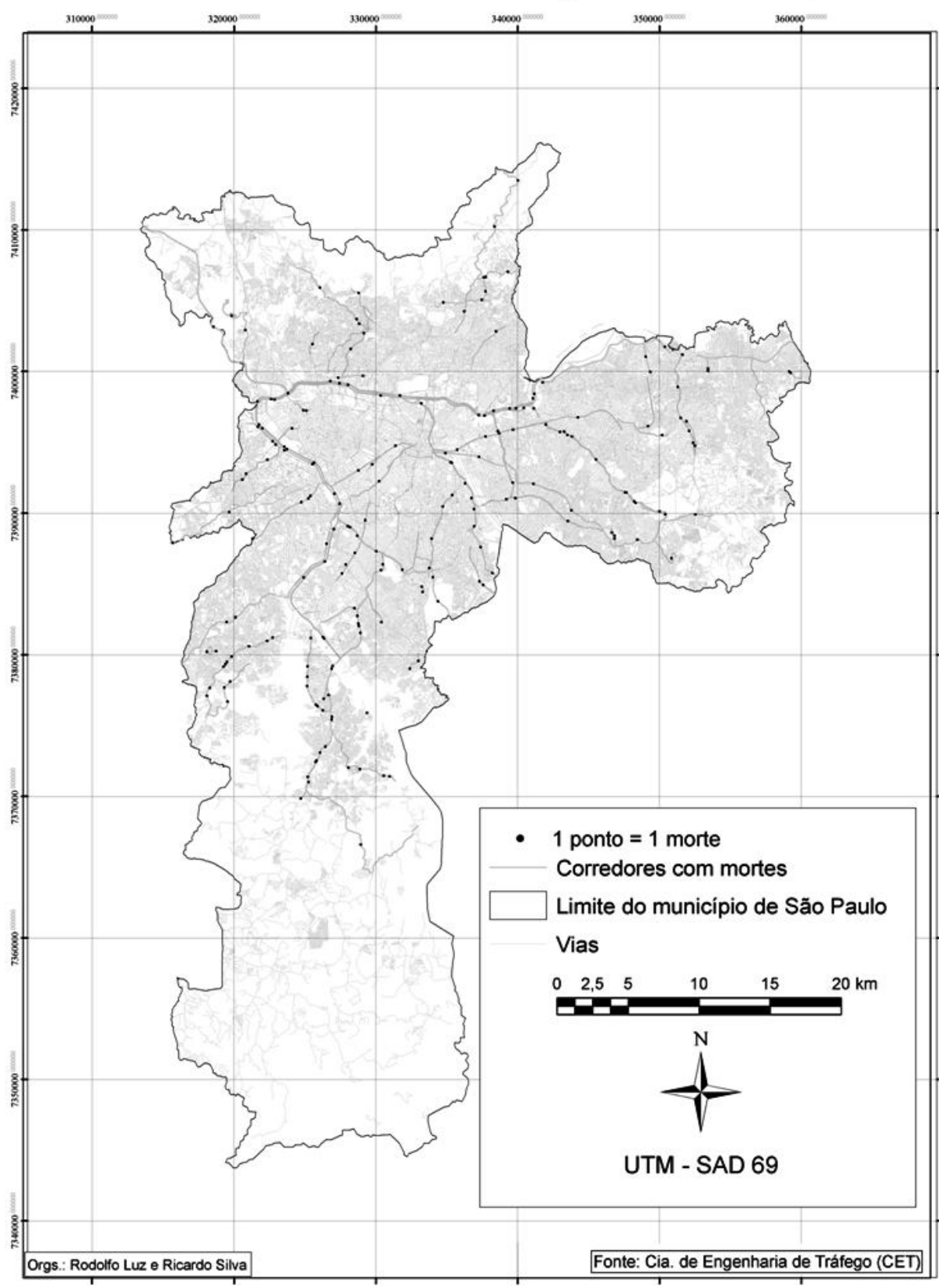




\section{Considerações Finais}

A atividade profissional dos motoboys, originada em meados da década de 80 e com maior intensidade nos prelúdios da década de 90 , aparece como produto e necessidade de um contexto histórico do capitalismo contemporâneo, revelando parte das transformações socioespaciais na cidade paulistana na transição do século XX para o XXI, encarnando dois pólos de um mesmo problema a partir da nova condição da cidade e do mundo do trabalho.

Essas transformações socioespaciais analisadas a partir da atividade profissional dos motoboys, além da possibilidade de uma nova condição da cidade e do mundo do trabalho, traduzem, também, uma nova prática socioespacial que a partir das exigências da circulação e do consumo em escala ampliada na cidade, vêm definindo os usos, as formas de apropriação, a intensidade de circulação e as condições de acessibilidades.

Todavia, se por um lado, essa nova prática socioespacial, vinculada às racionalidades da circulação e do consumo, tem no espaço seu elemento fundamental à sua realização, por outro lado, é nesse mesmo espaço que as contradições latentes manifestam-se, no limite último, dirimindo a própria essência da vida humana desses trabalhadores e trabalhadoras nas ruas e avenidas da metrópole de uma das maneiras mais brutais: ceifando-as.

Este artigo buscou enfatizar a questão da atividade profissional dos motoboys como produto e necessidade das transformações socioespaciais da cidade de São Paulo, traduzindo muito bem uma nova condição da cidade e do mundo do trabalho. É nesta ordem de considerações que entendemos que a atividade profissional dos motoboys pode revelar a cidade em trânsito para o século XXI, como uma problemática que remete à compreensão das práticas socioespaciais da maneira pela qual a sociedade vem concebendo, usando e se apropriando do espaço.

Uma nova prática socioespacial deveria mais do que apontar a mitigação das condições de trabalho dos motoboys e, sim, repensar uma nova espacialidade e reinventar novas formas de trabalho. É preciso refletir sobre a atividade caótica dos motoboys no trânsito de São Paulo, que no limite da lógica da circulação submete trabalhadores e trabalhadoras a sua desventura máxima: a perda da vida.

Portanto, faz-se necessário uma nova práxis em uma sociedade que vive cada vez mais confinada em suas casas, em seus carros, distanciando-se vertiginosamente da dimensão maior do sentido da vida e do uso consciente da cidade e não por acaso banaliza mecanicamente a sucessão de quedas dos motoboys nas ruas e avenidas da cidade de São Paulo.

Por fim, temos a noção de que estas indicações não pretendem esgotar quaisquer discussões e abordagens possíveis. Entrementes, ensejamos que nossa pequena contribuição colabore com o entendimento da atividade dos motoboys na cidade de São Paulo. Cremos que as soluções para esta atividade não se encerram em medidas pontuais e paliativas, mas sim, numa discussão em sentido amplo relacionada ao uso da cidade, da apropriação consciente e criativa de seus espaços, e quem sabe incitar a discussão sobre o direito de uso do espaço de forma mais consciente, ou mesmo repensar novas relações sociais que coloque em outro patamar a importância que o trabalho pode representar para além de uma atividade que exponha a vida de milhares de trabalhadores e trabalhadoras, às custas de uma dita racionalidade capitalista e, quem sabe assim, as pessoas compreendam que são parte integrante dessa problemática e da sua superação. 


\section{Notas}

1 Apesar da carência de um estudo especifico que vise quantificar a atividade profissional dos motoboys, segundo o Presidente do Sindicato dos Mensageiros Motociclistas, Ciclistas e Moto-Taxistas do Estado de São Paulo (Sindimoto-SP), Gilberto dos Santos, em entrevista disse-nos que existem "entre 200 e 250 mil só na cidade de São Paulo".

2 Maneira pejorativa pela qual muitos motoboys são denominados, principalmente aqueles que primam pela imperícia nas ruas e avenidas de São Paulo.

${ }^{3}$ Conforme Robert (CASTEL, 2005, p. 517) a "flexibilização é uma maneira de nomear essa necessidade do ajustamento do trabalhador moderno a sua tarefa". Porém, para ele o conceito abre um leque que pode se referir tanto à "polivalência" dos trabalhadores em se ajustar às mais diversas funções internas da empresa, quanto "subcontratação" se for externa (Castel, Ibid., 517).

${ }^{4}$ Em 2008, a motocicleta Honda CG 125 FAN e a Honda CG 150 Titan, representaram, respectivamente, $22,2 \%$ e $24,6 \%$ do total de vendas, isto é, algo em torno de $47 \%$ de todo o mercado nacional de motocicletas. Fonte: http:/ $\angle$ abraciclo.com.br/dsuploads/ven2008.pdf. Acessado em 06/08/09.

${ }^{5}$ Cf. Jornal Agora São Paulo, 28 de maio de 2009. Segundo a matéria, esse crédito poderá ser concedido pelo Banco do Brasil e Caixa Econômica Federal aos motoboys desde que estejam regularizados junto aos órgãos competentes.

${ }^{6}$ No consórcio Honda, a moto pode sair por sorteio - saem 13 motos de um grupo fechado de 900 pessoas - ou por um lance que varia de 25 a $30 \%$. Fonte: www.honda.com.br. Acessado em 06/08/2009.

7 Refere-se ao transporte de pessoas através de uma motocicleta, especialmente, como um fenômeno mais localizado em cidades pequenas e médias, com exceção do Rio de Janeiro. Porém, mesmo que instigante, não é intenção desta pesquisa desenvolver as razões socioespaciais para o desenvolvimento dessa atividade no Rio de Janeiro e não em São Paulo.
8 Jane JACOBS. Morte e vida de grandes cidades, 1961.

${ }^{9} \mathrm{O}$ total da frota de motocicletas no ano de 2008 é referente ao total no mês de dezembro. www.denatran.gov.br, http:// www2.cidades.gov.br/renaest/ detalheNoticia.do?noticia.codigo $=120$. Acessado em 06/08/2009.

10 Conforme metodologia do Detran-SP, a frota de motocicleta inclui, além das próprias motocicletas, ciclomoto, motoneta, motociclo, triciclo e quadriciclo. Os dados tem como referência o mês de janeiro de cada ano. http:// www.detran.sp.gov.br/frota/frota.asp. Acessado em 06/08/2009.

${ }^{11}$ Perfil dos condutores de motocicletas. Monitoração da segurança. Companhia de Engenharia de Tráfego. Diretoria de operações - DO. Superintendência de Projetos - SPR. Gerencia de Projetos Viarios - GPV/Pesquisa/março de 2002.

${ }^{12}$ Perfil dos condutores de motocicletas. Monitoração da segurança. Companhia de Engenharia de Tráfego. Diretoria de operações - DO. Superintendência de Projetos - SPR. Gerencia de Projetos Viários - GPV/ Pesquisa/setembro de 2003.

${ }^{13}$ Porém, mesmo em posse desses dados não é possível generalizar e afirma que os motoboys compõem a maioria do universo dos motociclistas na cidade paulistana, isso porque é relativamente mais fácil encontrar os motoboys que circulam e se estabelecem por mais tempo nas ruas e avenidas do que aqueles que usam a motocicleta para o trabalho e lazer.

14 Jovem é conceituado pela Organização das Nações Unidas (ONU) como o grupo etário de 15 a 24 anos, embora reconheça a possibilidade de variação de país para país, conforme as "circunstâncias políticas, econômicas e socioculturais" (ONU, 1995). No Brasil, o Estatuto da Criança e do Adolescente - ECA - considera adolescentes aqueles que têm entre 12 e 18 anos incompletos (Brasil, 1990). Já o Plano Nacional da Juventude, em tramitação no Congresso Nacional, dirige-se à faixa etária de 15 a 29 anos (Brasil, 2004). Segundo o Censo Demográfico do IBGE, 
em 2000, havia 2.956. 211 pessoas entre 15 e 29 anos na cidade de São Paulo, que corresponde a 28,3\% da população. Assim, conforme Cubides C., Humberto et al, (1990), entendemos que o campo da juventude não está restrito a uma fase biológica, mas sim a um tempo social construído pelas condições socioculturais de cada país. Assim, o recorte temporal refere-se ao contexto particular brasileiro e da atividade profissional que se trata, no caso dos motoboys entre 18 a 29 anos. A título de esclarecimento recortamos a partir dos dezoito anos, já que é a idade mínima para concessão da Carteira Nacional de Habilitação $(\mathrm{CNH})$, categoria A, conforme o Código Brasileiro de Trânsito (art. 140), mesmo tendo ciência que muitos trabalham ativamente antes dos dezoito e, portanto, sem a $\mathrm{CNH}$.

${ }^{15}$ Não por acaso que a maior ocupação dos espaços por automóveis em detrimento dos transportes coletivos vem influenciando diretamente nos altos índices de congestionamento registrados na cidade de São Paulo. Mais recentemente, em junho de 2009, o recorde de congestionamento chegou à marca dos 293 km de lentidão, conforme http:// www 1 . folha.uol.com.br/folha/cotidiano/ ult95u579653.shtml. Acessado em 11/08/2009.

${ }^{16}$ http://www.nossasaopaulo.org.br/portal/node/224. Acessado em 05/08/2008. Este estudo levou em consideração a pesquisa do Ipea (Instituto de Pesquisas Aplicadas) para calcular quanto a sociedade perde com desastres no trânsito urbano e tendo os dados atualizados a partir da variação do IGP-M, índice que mede a inflação, entre 2003 e 2008. Desse total gasto com acidentes envolvendo motocicleta, R\$323.317.0004,85 referem-se aos acidentes com vítimas ( $\mathrm{R} \$$ $22.768,80$ cada vítima) e $\mathrm{R} \$ 49.916 .526,80$ aos cidentes fatais ( $R \$ 143.069,13$ cada vítima). Nesta estimativa é analisada também a composição dos custos do total dos custos com os acidentes de motocicletas, R\$ 160 milhões (43\%) referem-se à perda de produtividade das pessoas envolvidas nas ocorrências, $\mathrm{R} \$ 112$ milhões (30\%) à danos a propriedade (veículos), R\$ 60 milhões (16\%) vinculam-se aos custos médicos (tratamento e reabilitação), R\$ 41 milhões (11\%) ligados a outros custos (judiciais, congestionamentos, impacto familiar, etc.).

\section{Referências Bibliográficas}

ALVES, Giovanni. O Novo (e Precário) Mundo do Trabalho: reestruturação produtiva e crise do sindicalismo. São Paulo: FAPESP: Boitempo Editorial, 2000.

ANTUNES, Ricardo. Adeus ao Trabalho? Ensaio sobre as metamorfoses e a centralidade do mundo do trabalho. São Paulo: Cortez, Campina: 2003.

BENKO, Georges. Economia, Espaço e Globalização. São Paulo: Hucitec, 1996.

CACCIAMALI, Maria. Globalização e Processo de Informalidade. Economia e Sociedade, IE, UNICAMP, São Paulo, n.14, p. 153-175, jul.2000.

CACCIAMALI, Maria C. e BRITTO, André. Flexibilização Restrita e Descentralizada das Relações de Trabalho no Brasil. Revista Brasileira de Estudos do Trabalho, vol.2, n.2, 2002. p.91120
CARLOS, Ana Fani. Espaço-Tempo na Cidade. São Paulo: Ed. Contexto, 2001.

CASTEL, Robert. As metamorfoses da questão social: uma crônica do salário. Petrópolis: Vozes, 2003.

CASTELLS, Manuel. Sociedade em Rede. A Era da Informação. São Paulo: Paz e Terra, 1999.

COMPANHIA DE ENGENHARIA E TRÁFEGO - CET. Motocicletas - Evolução do número em circulação, 1995/2001.

.Evolução do Número em Circulação, Acidentes e Vítimas. Monitoração da Segurança, 20001.

.São Paulo Reduz os Acidentes de Trânsito. Ações de segurança.

.Desempenho do Sistema Viário. Monitoração da Fluidez, vol. 2003. 
COMPANHIA DE ENGENHARIA E TRÁFEGO - CET. Acidentes de Trânsito Fatais no Município de São Paulo, 2005.

Pesquisa Qualitativa Motociclista. Club de Pesquisa Opinião \& Mercado, 2005.

. Locais mais Perigosos de São Paulo. Sumário de Dados, 2006.

- Mortes em Acidentes de Trânsito no Município de São Paulo, 2006

CARLOS, Ana Fani. Espaço-Tempo na Cidade. São Paulo: Ed. Contexto, 2001.

DINIZ, Eugênio Pacelli Hatem. Entre as Exigências de tempo e os Contrangimentos do Espaço: As condições acidentogênicas e as estratégias de regulamentação dos motociclistas profissionais. Dissertação (Mestrado em Engenharia da Produção) UFMG. Minas Gerais, 2003.

GOTTDiener, Mark. A Teoria da Crise e a Reestruturação sócio-espacial: o caso dos EUA. In: Orgs. PRETECEILLE, Edmund e VALLADARES, Lícia. A Reestruturação Urbana. São Paulo: Nobel, 1990.

HARVEY, David. A Condição Pós-Moderna - Uma Pesquisa sobre as Origens da Mudança Cultural. São Paulo: Ed. Loyola, 1996.

HOBSBAWM, Eric. Era dos Extremos: o breve século XX (1914-1991). São Paulo: Companhia das Letras, 2003.

INSTITUTO DE PESQUISA ECONÔMICA APLICADA - IPEA. Impactos sociais e econômicos dos acidentes de trânsito nas aglomerações urbanas brasileiras. Brasília, 2003

LEFEBVRE, Henri. O Direito à Cidade. São Paulo: Documentos, 1969.

. A Vida Cotidiana no Mundo Moderno. São Paulo: Ática, 1991.

LENCIONE, Sandra. Mudanças na Metrópole de São Paulo (Brasil) e Transformações Industriais. Revista do Departamento de Geografia no 12, p.27-42, 1998.

LEMOS, Amália Inês Geraiges de. São Paulo: $A$ Metrópole Financeira da América do Sul. In:
Geografias de São Paulo: A Metrópole do Século XXI. Orgs. Carlos, Ana Fani \& Oliveira, Ariovaldo Umbelino. São Paulo: Contexto, 2004.

MARTINS, Heloísa H. A Terceirização no Contexto da Globalização da Economia. Araraquara, 1994. In Temas/ org. Blass, Leila Silva. Araraquara: Unesp, 1994.

MARTINS, Renato; DOMBROWSKI, Osmir et al. Mapa do Trabalho Informal na Cidade de São Paulo. São Paulo: Ed. Fundação Perseu Abramo, 2000.

MARX, Karl. O Capital - Crítica da Economia Política. Livro Primeiro. O processo de produção do capital. São Paulo: Ed. Nova Cultural, 1998.

. O Capital - Crítica da Economia Política. Livro Segundo. O processo de circulação do capital. Vol.III. Rio de Janeiro: Civilização Brasileira, 1970.

OLIVA, Jaime Tadeu. O Automóvel como Elemento Constituinte e Constituidor da Cidade de São Paulo. Doutorado (Geografia Humana) USP. São Paulo, 2004.

OLIVEIRA, Gilvando Conceição. Trabalho, Vitimização e criminilização no cotidiano de motoboy de Salvador. Dissertação (Mestrado em Saúde Pública) UFBA. Salvador, 2003.

OLIVEIRA, Francisco. Crítica à Razão Dualista: O Ornitorrinco. São Paulo: Ed. Boitempo, 2003

POCHMANN, Márcio. A Inserção Ocupacional e o Emprego dos Jovens. São Paulo: ABET, 1998.

SANTOS, Milton. Técnica, Espaço, Tempo. Globalização e Meio Técnico-Científico Informacional: Ed. Hucitec. São Paulo, 1994.

. A Natureza do Espaço - Técnica e tempo, razão e emoção. São Paulo: Edusp. 2002. Paulo, 2005.

Urbanização Brasileira: Edusp. São

SCARLATO, Francisco Capuano. A expansão da Indústria Automobilística e Metropolização de São Paulo. Mestrado (Geografia Humana) USP. São Paulo, 1981. 
SCHOR, Tatiana O Automóvel e a cidade de São Paulo: a territorialização do processo de modernização (e de seu colapso). Mestrado (Geografia Humana) USP. São Paulo, 1999.
SOJA, Edward W. Geografias Pós-modernas. A reafirmação do espaço na teoria social crítica. Jorge Zahar Editor: Rio de Janeiro, 1993.

Trabalho enviado em outubro de 2009

Trabalho aceito em dezembro de 2009 